The Lahore Journal of Economics

$11: 2$ (Winter 2006) pp. 71-77

\title{
Population Growth and Economic Development: Test for Causality
}

\section{Khalid Mushtaq*}

\begin{abstract}
This paper examines the existence of a long-run relationship between population and per capita income in Pakistan for the period 19602001 using cointegration analysis. Unit root results show that population is integrated of order zero while per capita income is integrated of order one; further, Johansen's procedure show that no long-run cointegrating relationship exists. Thus, population growth neither causes per capita income growth nor is caused by it. A corollary is that population growth neither stimulates per capita income growth nor reduces it.
\end{abstract}

\section{Introduction}

The relationship between population growth and economic development has long been theoretically and empirically analyzed by various schools of thought in economics. Most development economists believe that rapid population growth is detrimental to growth. Population growth reduces savings and the capital-1abor ratio. It raises the dependency ratio, and puts strains on education and health systems as well as the food supply. Larger and larger populations may also contribute to environmental degradation.

However, there are also some who believe that population growth promotes economic development. They argue that population growth stimulates consumer demand, allowing a country to take greater advantage of economies to scale. At the same time, a large population can provide a large and cheap labor supply, as well as be a source of innovation. Some also claim that rural areas are under-populated in some countries in Africa and Latin America, leaving arable land uncultivated.

\footnotetext{
* The author is Assistant Professor in the Department of Agricultural Economics, University of Agriculture, Faisalabad, Pakistan.
} 
For example, Thirwall (1994: p.143) states that,

"The relation between population growth and economic development is a complex one, and the historical evidence is ambiguous, particularly concerning what is cause and what is effect. Does economic development precede population growth, or is population growth a necessary condition for economic development to take place? Is population growth an impediment or a stimulus to economic development?"

Following Thirlwall (1972), this paradox can be summarized using the identity: $\mathrm{Y}=\mathrm{P}(\mathrm{Y} / \mathrm{P})$ where $\mathrm{Y}$ is output or income and $\mathrm{P}$ is population. Totally differentiating and dividing by $\mathrm{Y}$ gives: $\mathrm{d} \mathrm{Y} / \mathrm{Y}=\mathrm{dP} / \mathrm{P}+\mathrm{d}(\mathrm{Y} / \mathrm{P}) /(\mathrm{Y} / \mathrm{P})$. The relationship between the two terms on the right hand side i.e., population growth and per capita income growth is crucial: if the relationship is positive, population growth unambiguously increases both per capita and aggregate income; while if the relationship is negative, per capita income (and hence living standards) fall.

Hagen (1959) distinguishes between exogenous and induced population growth, implying an ambiguity regarding the causality with per capita income growth. If population growth is exogenous, there are two relevant hypotheses: should population growth cause per capita income growth, the former is an impediment to rising living standards if there is an adverse effect on both savings and the capital: labor ratio - the hypothesis of Coale and Hoover (1958); conversely, population growth (and growth of the labor force) can stimulate living standards if specialization and scale economies occur. Alternatively, population growth is endogenous if technological improvements increase per capita income, which improves health and lowers the death rate thereby increasing the population. These arguments are well known [e.g. Kelley (1988) or Simon (1992: part 2)].

This paper tests the causality between population and per capita income in Pakistan for 1960-2001 using cointegration analysis. The paper is structured as follows: Section 2 discusses the empirical method, Section 3 discusses the data and results, and Section 4 concludes.

\section{Empirical Method}

Many time series are non-stationary and in general OLS regressions between such data are spurious. The presence of a unit root in the autoregressive representation of a time series leads to non-stationarity, and such series, referred to as being integrated of order one (I(1)), must be first- 
differenced to render them stationary (or integrated of order zero). Where the I(1) series move together and their linear combination is stationary, they are referred to as being cointegrated and the problem of spurious regression does not arise. Cointegration implies the existence of a meaningful long-run equilibrium (Granger, 1988). Since a cointegrating relationship cannot exist between two variables which are integrated of a different order, we first test for the order of integration of the variables.

We begin by testing for the presence of unit roots in the individual time series using the augmented Dickey-Fuller (ADF) test [Dickey and Fuller (1981); Said and Dickey (1984)], both with and without a deterministic trend. The number of lags in the ADF-equation is chosen to ensure that serial correlation is absent using the Breusch-Godfrey statistic (Greene (2000), p.541)). In testing for unit roots using the augmented Dickey-Fuller (ADF) test, we follow the sequential procedure of Dickey and Pantula (1987): the null of the largest possible number of unit roots, assumed to be three, is tested and, if rejected, that of two unit roots is tested and so on until the null is not rejected. If the variables are integrated of the same order, Johansen's (1988) procedure can then be used to test for the presence of a cointegrating vector between population and income. The procedure is based on maximum likelihood estimation of the error correction mode1:

$$
\Delta z_{t}=\delta+\Gamma_{1} \Delta z_{t-1}+\Gamma_{2} \Delta z_{t-2}+\cdots+\Gamma_{p-1} \Delta z_{t-p+1}+\pi z_{t-p}+u_{t}
$$

where $z_{t}$ is a vector of $\mathrm{I}(1)$ endogenous variables, $\Delta z_{t}=z_{t}-z_{t-1}$, and $\pi$ and $\Gamma_{i}$ are $(n \times n)$ matrices of parameters with $\Gamma_{i}=-\left(I-A_{1}-A_{2}-\ldots-A_{i}\right),(i=1, \ldots, k-1)$, and $\pi=I-$ $\pi_{1}-\pi_{2}-\ldots-\pi_{\mathrm{k}}$. The term $\pi \mathrm{z}_{\mathrm{t}-\mathrm{p}}$ provides information about the long-run equilibrium relationship between the variables in $z_{t}$. Information about the number of cointegrating relationships among the variables in $z_{t}$ is given by the rank of the $\pi$-matrix: if $\pi$ is of reduced rank, the model is subject to a unit root; and if $0<\mathrm{r}<\mathrm{n}$, where $\mathrm{r}$ is the rank of $\pi, \pi$ can be decomposed into two $(n \times r)$ matrices $\alpha$ and $\beta$, such that $\pi=\alpha \beta^{\prime}$ where $\beta^{\prime} z_{t}$ is stationary. Here, $\alpha$ is the error correction term and measures the speed of adjustment in $\Delta z_{t}$ and $\beta$ contains $r$ distinct cointegrating vectors, that is the cointegrating relationships between the non-stationary variables. Equation (1) can be rewritten in full as:

$$
\left[\begin{array}{l}
\Delta \mathrm{P}_{\mathrm{t}} \\
\Delta(\mathrm{Y} / \mathrm{P})_{\mathrm{t}}
\end{array}\right]=\left[\begin{array}{l}
\delta_{1} \\
\delta_{2}
\end{array}\right]+\sum_{\mathrm{i}=1}^{\mathrm{p}-1}\left[\begin{array}{ll}
\Gamma_{\mathrm{i}, 11} & \Gamma_{\mathrm{i}, 12} \\
\Gamma_{\mathrm{i}, 21} & \Gamma_{\mathrm{i}, 22}
\end{array}\right]\left[\begin{array}{l}
\Delta \mathrm{P}_{\mathrm{t}-\mathrm{i}} \\
\Delta(\mathrm{Y} / \mathrm{P})_{\mathrm{t}-\mathrm{i}}
\end{array}\right]+\left[\begin{array}{l}
\alpha_{1} \\
\alpha_{2}
\end{array}\right]\left[\beta_{1} \beta_{2}\right]\left[\begin{array}{l}
\mathrm{P}_{\mathrm{t}-\mathrm{p}} \\
(\mathrm{Y} / \mathrm{P})_{\mathrm{t}-\mathrm{p}}
\end{array}\right]+\left[\begin{array}{l}
\mathrm{u}_{1} \\
\mathrm{u}_{2}
\end{array}\right]
$$


The Johansen procedure estimates (1), and trace statistics are used to test the null hypothesis of at most $r$ cointegrating vectors against the alternative that it is greater than $r$. If cointegration exists between $P_{t}$ and $(\mathrm{Y} / \mathrm{P})_{\mathrm{t}}$, the model in (2) can then be used to test Granger-causality (Granger, 1969) in either direction or feedback between $P_{t}$ and $(Y / P)_{t}$.

\section{Data and Results}

Annual data for population (in millions) and real per capita income (in rupees) is used for Pakistan for 1960-2001. Population has trended upwards at a relatively constant rate, increasing by over 300 per cent from 46 million in 1960 to 142 million in 2001 at an average annual growth rate of 2.74 per cent. Real per capita income has also trended upwards but more erratically; it has increased from 397 rupees in 1960 to 24,314 rupees in 2001.

We examine the time series properties of the series, in logarithms, following the sequential testing procedure of Dickey and Pantula (1987) and test for up to three unit roots. Multiple unit roots in all series are rejected and Table-1 reports the results of testing for one unit root using ADF-tests both with and without a linear trend. Both models indicate that the series $P_{t}$ is stationary but the trend is significant and the series $(\mathrm{Y} / \mathrm{P})_{t}$ has a unit root and the trend is insignificant. It is clear that $\mathrm{P}_{t}$ is trend stationary, that is, integrated of order zero, $\mathrm{I}(0)$, while $(\mathrm{Y} / \mathrm{P})_{\mathrm{t}}$ is non-stationary, that is $\mathrm{I}(1)$, and is stationary in differences.

Table-1: ADF-Tests for Unit Roots

\begin{tabular}{lcc}
\hline \multicolumn{1}{c}{ Variable } & Non-Trended Model & Trended Model \\
\hline $\mathrm{P}_{\mathrm{t}}$ & -3.37 & 0.33 \\
$(\mathrm{Y} / \mathrm{P})_{\mathrm{t}}$ & -0.62 & -2.62 \\
Crit. Value & -2.93 & -3.50 \\
\hline
\end{tabular}

Note: Critical values (95\% confidence level) are taken from Fuller (1976, p. 373)

The above conclusions are also substantiated by applying PhillipsPerron unit root tests (from the paper Phillips and Perron (1988)). That $P_{t}$ is $I(0)$ and $(Y / P)_{t}$ is $I(1)$ implies that a meaningful relationship between them cannot exist. However, the usefulness of unit root tests is contentious [e.g., Sims (1988)] and Holden and Perman (1994: p.88-9) 
argue that using the Johansen procedure obviates the need for unit root tests since the existence of a cointegrating relationship between two variables implies the presence of unit roots. Accordingly, Equation (1) is estimated assuming that the variables and the data generating process have deterministic trends. Table- 2 shows the trace statistics and results indicate that no cointegrating vector is present so that a long-run relationship between population and per capita income does not exist.

Table-2: Cointegration Results

\begin{tabular}{crr}
\hline $\mathrm{H}_{0}$ & \multicolumn{2}{c}{ Trace Statistics } \\
\hline $\mathrm{r}=0$ & 15.23 & $(25.77)$ \\
$\mathrm{r} \leq 1$ & 5.42 & $(12.39)$ \\
\hline
\end{tabular}

Note: Critical values in the parentheses.

\section{Conclusions}

This paper examines the possible existence of a long-run relationship between population growth and per capita income growth in Pakistan for 1960-2001 using cointegration analysis. We find that the population is trend stationary, while per capita income has a unit root; hence a long-run relationship between the two variables cannot exist. Since the testing for unit roots is contentious, we also apply Johansen's procedure to test for cointegration between the two variables; no cointegrating vector can be found, confirming the conclusions of the unit root tests. Thus, population growth neither causes per capita income growth nor is caused by it. A corollary is that population growth neither stimulates per capita income growth nor detracts from it.

If our result is generalized, any such statistically significant correlation in the literature is spurious. Our results also confirm that inappropriate inferences have sometimes been drawn from simple correlations or from regressions in previous studies using cross section data which sometimes purport to demonstrate causality, or at least, in Simon's (1992: p.200-21) case of non-causality in one direction. In reviewing these cross section results, Simon (1992: p.205) asks, 'do these studies imply that there is no long-run positive effect?' Our results indicate that there is no long-run effect, positive or negative; causality therefore is not an issue. 


\section{References}

Coale, A.J. and E.M. Hoover, 1958, Population Growth and Economic Development in Low Income Countries, Princeton, NJ: Princeton University Press.

Dickey, D.A., and S.G. Pantula, 1987, Determining the Order of Differencing in Autoregressive Processes. Journal of Business and Economic Statistics, 15: 455-461.

Dickey, D.A., and W.A. Fuller, 1981, Likelihood Ratio Statistics for Autoregressive Time Series with a Unit Root. Econometrica, 49: 1057-1072.

Fuller, W.A., 1976, Introduction to Statistical Time Series. Wiley, New York.

Government of Pakistan. Economic Survey (various issues), Finance Division, Economic Adviser's Wing, Islamabad.

Granger, C.W.J., 1969, Investigating Causal Relations by Econometric Methods and Cross-Spectral Methods, Econometrica, 37(4): 424-36.

Granger, C.W.J., 1988, Some Recent Developments in a Concept of Causality. Journal of Econometrics, 39 199-211.

Greene, W.H., 2000, Econometric Analysis. New Jersey: Prentice-Hall, Inc.

Hagen, E., 1959, Population and Economic Growth, American Economic Review, 49(3): 310-327.

Holden, D. and R. Perman, 1994, Unit Roots and Cointegration for the Economist. Ch.3 in B.B. Rao, (ed), Cointegration for the Applied Economist, New York: St. Martin's Press.

Johansen, S., 1988, Statistical Analysis of Cointegrating Vectors. Journal of Economic Dynamics and Control 12: 231-254.

Kelley, A.C., 1988, Economic Consequences of Population Change in the Third World, Journal of Economic Letters, 26(4): 1685-1728.

Phillips, P.C.B. and P. Perron, 1988, Testing for a Unit Root in Time Series Regression, Biometrika, 75(2): 335-346. 
Said, S.E. and D.A. Dickey, 1984, Testing for Unit Roots in AutoregressiveMoving Average Models of Unknown Order. Biometrica, 71:599607.

Simon. J.L., 1992, Population and Development in Poor Countries, Princeton, NJ: Princeton University Press.

Sims, C.A., 1988, Bayesian Skepticism on Unit Root Econometrics, Journal of Economic Dynamics and Control, 12(2-3): 463-474.

Thirlwall, A.P., 1972, A Cross Section Study of Population Growth and the Growth of Output and Per Capita Income in a Production Function Framework, The Manchester School, 40(4): 339-356.

Thirlwall, A.P., 1994, Growth and Development, Basingstoke: Macmillan Press. 